\section{Cap methyltransferase selective binding and methylation of GpppG-RNA are stimulated by importin- $\alpha$}

\author{
Yingxia Wen ${ }^{1,2}$ and Aaron J. Shatkin ${ }^{1,3}$ \\ ${ }^{1}$ Center for Advanced Biotechnology and Medicine and \\ ${ }^{2}$ Graduate Program in Molecular Genetics and Microbiology, \\ University of Medicine and Dentistry of New Jersey, \\ Piscataway, New Jersey 08854, USA
}

We screened a human cDNA library for proteins that bind mRNA cap methyltransferase (MT) and isolated nuclear transporter importin- $\alpha$ (Imp $\alpha)$. This direct association was confirmed by glutathione $S$-transferase (GST) pulldown, coimmunoprecipitation, and nuclear colocalization. In gel shift assays, MT selectively bound RNA containing 5'-terminal GpppG, and binding was inhibited by GpppG and not by $\mathrm{m}^{7} \mathrm{GpppC}$. Imp $\alpha$ markedly enhanced MT binding to GpppG-RNA and stimulated MT activity. MT/RNA/Imp $\alpha$ complexes were dissociated by importin- $\beta$, which also blocked the stimulation of cap methylation by Imp $\alpha$. The presence of RanGTP but not RanGDP prevented these effects of importin- $\beta$. These findings indicate that importins play a novel role in mRNA biogenesis at the level of cap methylation.

Received September 6, 2000; revised version accepted October $24,2000$.

The $5^{\prime}$-terminal $\mathrm{m}^{7} \mathrm{GpppN}$ cap, which is formed cotranscriptionally on nascent nuclear pre-mRNAs, is important for subsequent steps in gene expression, including mRNA processing, stability, and translation (Furuichi and Shatkin 2000). Cap formation is catalyzed by the sequential action of RNA 5'-triphosphatase (RT), guanylyltransferase (GT), and methyltransferase (MT) (Shuman 1995). In mammalian cells, RT and GT catalytic activities are present in a bifunctional capping enzyme (CE), whereas MT is separately encoded (Yue et al. 1997; Pillutla et al. 1998; Tsukamoto et al. 1998; Saha et al. 1999). Selective capping of RNA polymerase II (Pol II) products is facilitated by binding of CE via its GT domain to RNA (Wen et al. 1998) and to the Pol II largest subunit C-terminal domain (CTD) after it is phosphorylated (Cho et al. 1997; McCracken et al. 1997; Yue et al. 1997). Interaction with phosphorylated CTD stimulates capping (Ho and Shuman 1999; Wen and Shatkin 1999), which is also enhanced by binding of Pol II elongation factor Spt5 to CE (Wen and Shatkin 1999).

[Key Words: mRNA cap methyltransferase; 5' capping; RNA binding; importin; nuclear entry; RanGTP]

${ }^{3}$ Corresponding author.

E-MAIL shatkin@cabm.rutgers.edu; FAX (732) 235-5318.

Article and publication are at www.genesdev.org/cgi/doi/10.1101/ $\operatorname{gad} .848200$.
These protein-protein interactions demonstrated a functional linkage between CE and transcription; therefore, we looked for proteins that interact functionally with MT. We isolated importin- $\alpha(\operatorname{Imp} \alpha)$ and found that it forms complexes with MT and RNA and stimulates selective GpppG-RNA binding and cap methylation by MT. Imp $\alpha$ is an adapter that functions together with the importin- $\beta(\operatorname{Imp} \beta)$ receptor to promote nuclear import of proteins through the nuclear pore complex (Mattaj and Englmeier 1998; Görlich and Kutay 1999; Nakielny and Dreyfuss 1999). The effects on MT RNA binding and cap methylation indicate that importins can also modulate mRNA formation.

Results

\section{MT binds Imp $\alpha$ in vitro and in vivo}

A human cDNA library screened as described (Wen and Shatkin 1999) with full-length human MT in a yeast two-hybrid system yielded several candidate clones, including four with a perfect sequence match to Imp $\alpha$ isoform Rch1/pendulin/hSRP1 $\alpha$ (Weis et al. 1995; Kohler et al. 1999). Direct association of MT and Impo was demonstrated by glutathione $S$-transferase (GST) pulldown assays in which $24 \%$ of the input $\operatorname{Imp} \alpha$ specifically bound to purified GST-MT (Fig. 1A); similar results were obtained with bacterially expressed, affinity-purified proteins by using Western blot analysis (data not shown). The complexes were relatively stable, that is, $>60 \%$ remained bound after washing with $0.5 \mathrm{M} \mathrm{NaCl}$ (data not shown). This interaction was confirmed using input MT and GST-Imp $\alpha$ (Fig. 1B).

Consistent with these in vitro binding studies and the yeast two-hybrid results, HeLa S3 cells that were cotransfected with plasmids for the expression of green fluorescent protein (GFP)-Imp $\alpha$ and MT-myc fusion proteins contained complexes that were coimmunoprecipitable from cell lysates (Fig. 1C). In addition, GFP-MT and red fluorescent protein (RFP)-Imp $\alpha$ expression produced fusion proteins that colocalized in the nucleus (Fig. 2A-C).

Sequences required for MT/Imp $\alpha$ complex formation and nuclear recruitment of $M T$

The 476-amino acid human MT contains sequences that are conserved in yeast, Caenorhabditis elegans, and Xenopus laevis (Mao et al. 1995; Pillutla et al. 1998; Tsukamoto et al. 1998; Saha et al. 1999; Yokoska et al. 2000), including residues required for $S$-adenosylmethionine (Adomet) binding (201-L[D/E]XGXGXG) (Pillutla et al. 1998) and MT catalytic activity (D203, R239, Y289, F291, and F354) (Saha et al. 1999). More than $80 \%$ of the activity was retained by a fragment of human MT consisting of residues 144-476, whereas fragments 1-200 and $201-476$ had $<10 \%$ of the activity of the full-length MT (Fig. 3A). In contrast to requirements for MT activ- 
A

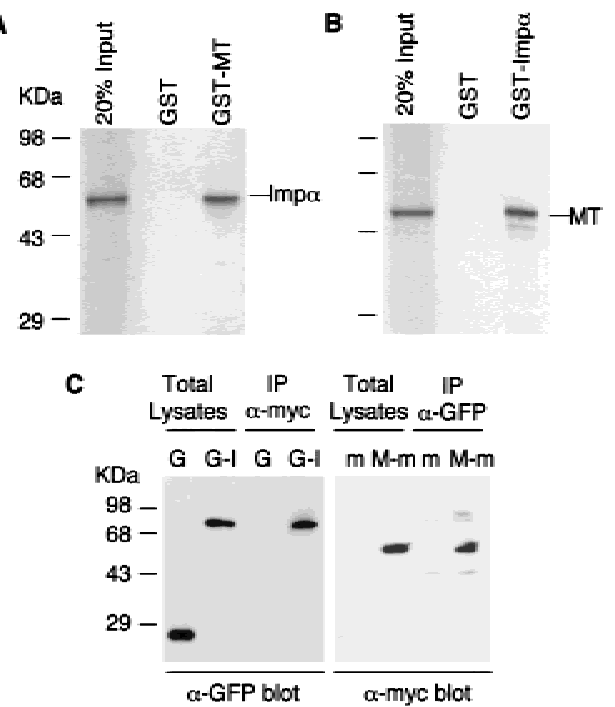

Figure 1. MT/Imp $\alpha$ binding. Purified GST and GST-MT $(A)$ or GST-Imp $\alpha(B)$ were incubated with $\left[{ }^{35}\right.$ S]Met-labeled Imp $\alpha$ and $\mathrm{MT}$, respectively. Bound proteins were detected by SDS-PAGE followed by autoradiography (Yue et al. 1997; Wen et al. 1998). HeLa S3 cells $(C)$ were transfected with pEGFP-C1-Imp $\alpha$ and pcDNA3.1(+)-MT-myc. Two days later, cell lysates were immunoprecipitated (IP) in RIPA buffer (see Materials and Methods) as indicated, with anti-myc $(\alpha-\mathrm{myc})$ or anti-GFP $(\alpha-\mathrm{GFP})$ antibodies, and immunoblotted with $\alpha$-GFP or $\alpha$-myc. (G) GFP only; (G-I) GFP-Imp $\alpha$ fusion protein; (m) myc tag only; (M-m) MTmyc fusion protein.

ity, GST pulldown assays showed that $\mathrm{N}$-terminal sequences are necessary for Imp $\alpha$ binding, in particular the 96-143 region that is rich in positively charged residues (Fig. 3A). Imp $\alpha$ contains a large central domain of tandemly repeated armadillo motifs responsible for nuclear localization signal (NLS) recognition, an Imp $\beta$-binding (IBB) N-terminal domain, and a C-terminal acidic region (Mattaj and Englmeier 1998; Görlich and Kutay 1999; Nakielny and Dreyfuss 1999). The Imp $\beta$-binding domain was not needed for MT binding, and the NLS-binding domain (72-455) was also not sufficient. However, sequences in the acidic region were essential (Fig. 3B). The required residues (456-496) contain many negatively charged amino acids, suggesting that $\operatorname{Imp} \alpha / \mathrm{MT}$ binding involves electrostatic interactions.

To test whether Imp $\alpha$ binding correlates with nuclear entry of MT, HeLa S3 cells were transfected with plasmids for expression of GFP fusions of either full-length MT or the N-terminal truncation mutant (144-476) that retained MT activity but not Imp $\alpha$ binding (Fig. 3A). Although full-length GFP-MT fusion protein was retained in the nucleus (Fig. 2A), the mutant missing the N-terminal Imp $\alpha$ binding sequence localized to the cytoplasm (Fig. 2D), consistent with nuclear recruitment by Imp $\alpha$.

\section{MT selectively binds RNA with 5'-terminal GpppG}

Previous studies have shown that CE can bind RNA (Wen et al. 1998) in addition to the phosphorylated form of Pol II (Cho et al. 1997; McCracken et al. 1997; Yue et al. 1997). To test whether MT also can directly associate with RNA, we used a gel mobility shift assay with ${ }^{32} \mathrm{P}$ labeled 32-nucleotide (nt) runoff transcripts containing 5'-terminal GpppG, pppG, or $\mathrm{m}^{7} \mathrm{GpppG}$ (Furuichi and Shatkin 1994; Buratowski and Chodosh 1996). Complexes detected by decreased RNA mobility were obtained only with the GpppG-ended RNA (Fig. 4A, lanes $1-3)$. The results were the same with 14-nt runoff transcripts (data not shown). Analysis of truncation mutants indicated that a region between residues 144 and 200 is required for RNA binding (Fig. 3A). Selective recognition was confirmed by cap analog competition; $1 \mathrm{mM} \mathrm{GpppG}$ but not $\mathrm{m}^{7} \mathrm{GpppC}$ almost completely (92\%) inhibited MT binding to the GpppG-ended RNA (Fig. 4A, lanes 4-6).

Imp $\alpha$ enhances $M T$ specific binding to and modification of RNA

Although MT selectively associated with GpppG-RNA, the complexes were apparently of low affinity, that is, readily detectable at $0.25 \mu \mathrm{M}$ but not at $0.1 \mu \mathrm{M}$ MT (Fig. $4 \mathrm{~B}$, lanes 2,3). Incubation of the GpppG-ended RNA probe with $1.0 \mu \mathrm{M}$ Imp $\alpha$ resulted in a new complex of decreased mobility and apparently high affinity (Fig. 4B, lane 6). Although not selective for 5'-terminal structure (because RNAs with pppG or $\mathrm{m}^{7} \mathrm{GpppG}$ ends were similarly bound by $\operatorname{Imp} \alpha$, and polyU in excess prevented Imp $\alpha$ but not MT binding to GpppG-ended RNA; data not shown), binding required a region within the $\operatorname{Imp} \alpha$ $\mathrm{N}$-terminal 71 amino acids (Fig. 3B), which is consistent with the presence of many basic residues (Weis et al. 1995). Imp $\alpha /$ RNA complexes were detectably shifted by
A

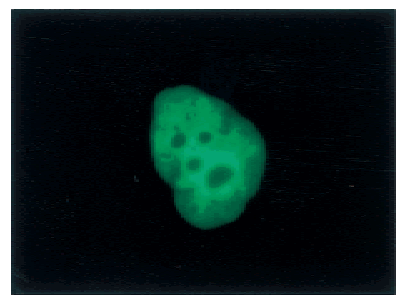

GFP-MT

C

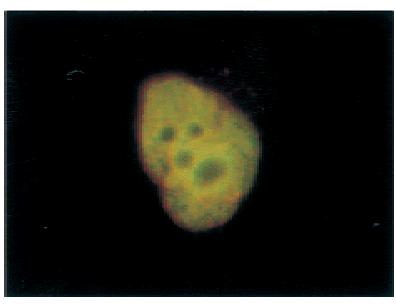

GFP-MT + RFP-Imp $\alpha$
B

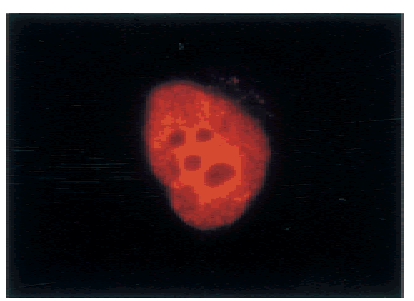

RFP-Imp $\alpha$
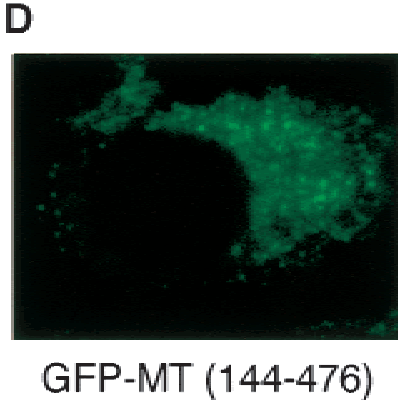

Figure 2. Localization of MT and Imp $\alpha$ fusion proteins. HeLa S3 cells were transfected with pEGFP-C1-MT and pDsRed1N1-Imp $\alpha(A-C)$ or pEGFP-C1-MT (144-476) (D), constructed as recommended by Clontech, and analyzed by fluorescence microscopy. 


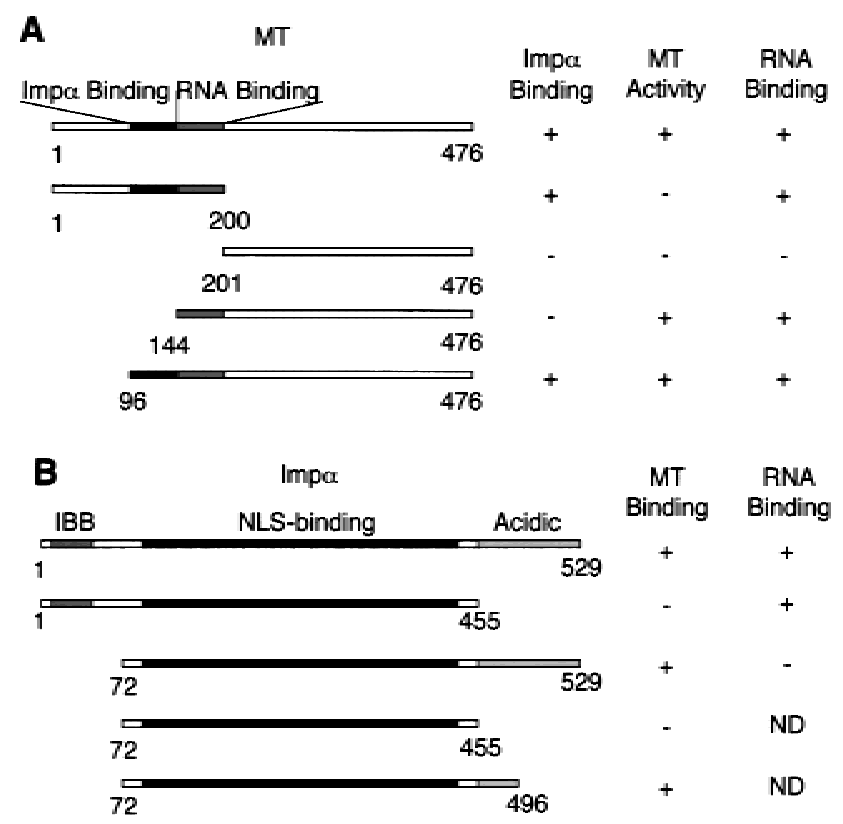

Figure 3. Regions required for Imp $\alpha / \mathrm{MT}$ complex formation, MT activity, and RNA binding in vitro. Purified MT $(A)$ or Imp $\alpha$ $(B)$ and the indicated truncation mutants fused with GST were incubated with $\left[{ }^{35} \mathrm{~S}\right]$ Met-labeled full-length Imp $\alpha$ or $\mathrm{MT}$, and bound proteins were detected by SDS-PAGE and autoradiography. MT activity was tested by incubating the indicated proteins with Adomet and T7 polymerase 32-nt runoff transcripts containing $\left[{ }^{32} \mathrm{P}\right]$ GpppG-5' ends, followed by $\mathrm{P} 1$ nuclease digestion, TLC, and autoradiography (Yue et al. 1997; Pillutla et al. 1998). RNA binding was measured using GpppG-primed T7 polymerase runoff transcripts labeled with $\left[\alpha{ }^{32} \mathrm{P}\right] \mathrm{GTP}$ (Furuichi and Shatkin 1994), and nucleoprotein complexes were separated by $4.5 \%$ PAGE at $4^{\circ} \mathrm{C}$ (Buratowski and Chodosh 1996) followed by autoradiography. The values corresponding to + and - were $>80 \%$ and $<10 \%$, respectively, of the levels obtained with the full-length protein. (ND) Not done.

the presence of MT at a concentration as low as $0.1 \mu \mathrm{M}$ (Fig. 4B, lane 7) and were supershifted at $0.25 \mu \mathrm{M}$ or higher levels (Fig. 4B, lanes 8-10). At $1 \mu \mathrm{M}$ (each) MT and $\operatorname{Imp} \alpha$, binding to GpppG-ended RNA was enhanced 8- to 10-fold (Fig. 4B, lane 10). However, Imp $\alpha$ (1-455) that retained RNA binding (Fig. 4B, lane 19) but not MT binding (Fig. 3B) did not supershift MT/RNA complexes (Fig. $4 \mathrm{~B}$, lane 20 ), suggesting that the $\operatorname{Imp} \alpha / \mathrm{MT}$ protein-protein interaction was required for the enhancement. Competition was again obtained with 1mM GpppG and not with $\mathrm{m}^{7} \mathrm{GpppC}$, resulting in dissociation of MT from most $(89 \%)$ of the trimeric complexes and the corresponding appearance of Imp $\alpha /$ RNA complexes (Fig. 4B, lanes 11-13). These results suggest that Imp $\alpha$ promotes specific binding of MT to its substrate GpppN-ended preRNAs in the nucleus. To examine further if Imp $\alpha$ stimulates MT catalytic activity by recruiting MT to GpppGRNA, we added Imp $\alpha$ to an MT reaction mixture. At an Imp $\alpha /$ MT molar ratio of 10:1, MT activity was increased 10-fold, whereas the truncation mutant Imp $\alpha$ (1-455), which did not bind MT, also did not stimulate methylation (Fig. 4C).

\section{Imp $\beta$ dissociates Imp $\alpha / M T / R N A$ complexes and blocks Impa stimulation of $M T$}

In the cytoplasm, $\operatorname{Imp} \beta$ forms heterodimers with $\operatorname{Imp} \alpha$, which, together with RanGDP, deliver NLS-containing protein cargo to the nucleus (Görlich et al. 1996; Mattaj and Englmeier 1998; Nakielny and Dreyfuss 1999). Imp $\beta$ alone did not bind directly to MT or to RNA and did not

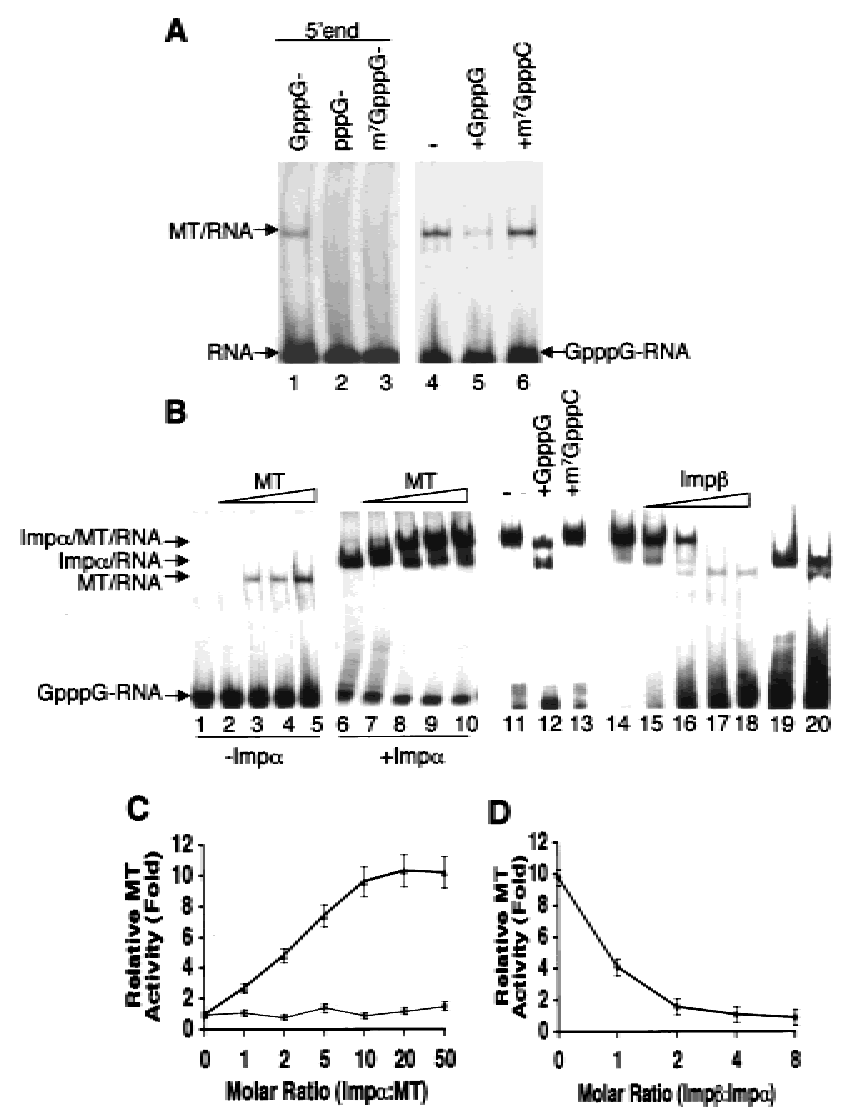

Figure 4. Imp $\alpha$ enhances MT selective binding to GpppGRNA and cap methylation, which are both prevented by $\operatorname{Imp} \beta$. (A) Purified MT was incubated with T7 polymerase 32-nt runoff transcripts labeled with $\left[\alpha{ }^{-32} \mathrm{P}\right] \mathrm{GTP}$ and containing $5^{\prime}$-terminal GpppG, pppG, or $\mathrm{m}^{7} \mathrm{GpppG}$ (Furuichi and Shatkin 1994) (lanes $1-3$, respectively) or 5 -teminal GpppG in the presence of $1 \mathrm{mM}$ cap analog, as indicated (lanes 4-6). The MT/RNA complexes were detected as in Fig. 3. (B) MT at 0 (lanes 1,6), 0.10 (lanes 2,7), 0.25 (lanes 3,8), 0.5 (lanes 4,9), or 1.0 (lanes 5,10 ) $\mu \mathrm{M}$ was incubated with GpppG-ended radiolabeled T7 polymerase runoff transcripts in the absence $(-)$ or presence $(+)$ of $1.0 \mu \mathrm{M}$ Imp $\alpha$. (Lanes 11-13) Samples contained the GpppG-RNA, 1.0 $\mu \mathrm{M}$ (each) Imp $\alpha$ and MT, and $1 \mathrm{mM}$ cap analog as indicated. (Lanes 14-18) Imp $\beta$ was added at concentrations of $0,1,2,4$, or $8 \mu \mathrm{M}$ with purified MT and Imp $\alpha(1.0 \mu \mathrm{M}$ each) and GpppG-RNA. (Lanes 19,20) GpppG-RNA was incubated with $1.0 \mu \mathrm{M} \operatorname{Imp} \alpha$ (1-455) and either 0 or $1.0 \mu \mathrm{M}$ purified MT, respectively. Nucleoprotein complexes were separated by PAGE, detected by autoradiography, and quantitated by PhosphorImager. (C) $3 \mathrm{nM}$ MT was incubated with $0,3,6,15,30,60$, or $150 \mathrm{nM} \operatorname{Imp} \alpha$ (closed triangles) or Imp $\alpha$ (1-455) (closed circles), and MT activity assays were performed as in Fig. 3. (D) 0, 30, 60, 120, or 240 $\mathrm{nM} \operatorname{Imp} \beta$ was incubated with $3 \mathrm{nM}$ MT and $30 \mathrm{nM} \operatorname{Imp} \alpha$ and assayed as above. 
affect Impa/MT complex formation as determined by GST pulldown and gel shift assays (data not shown), suggesting that it does not disrupt Imp $\alpha / \mathrm{MT}$ complexes in the cytoplasm. However, Imp $\alpha$ was dissociated from trimeric GpppG-RNA/MT/Imp $\alpha$ complexes by increasing levels of Imp $\beta$ (Fig. 4B, lanes 14-18). A 4 : 1 molar ratio of $\operatorname{Imp} \beta$ completely dissociated $\operatorname{Imp} \alpha$, and only MT/RNA complexes were detected (Fig. 4B, lane 17). Moreover, Imp $\beta$ alone did not affect MT activity (data not shown) but blocked the stimulatory effect on methylation by $\operatorname{Imp} \alpha$ (Fig. 4D). Addition of a fourfold molar ratio of $\operatorname{Imp} \beta$ to $\operatorname{Imp} \alpha$ essentially eliminated the enhancement.

\section{RanGTP but not RanGDP reverses the effects of Imp $\beta$}

RanGTP in the nucleus dissociates $\operatorname{Imp} \beta$ from $\operatorname{Imp} \alpha$, resulting in release of protein cargo (Görlich and Kutay 1999|. To assess the possible effects of Ran on MT activity and interactions with importins, we compared the dissociation of $\operatorname{Imp} \alpha / \mathrm{MT} / \mathrm{RNA}$ complexes by $\operatorname{Imp} \beta$ in the presence and absence of RanGTP or RanGDP. As shown in Figure 5A, lane 3, most of the supershifted complexes were dissociated into Imp $\alpha /$ RNA and MT/ RNA complexes by addition of $\operatorname{Imp} \beta$. This effect of $\operatorname{Imp} \beta$ was prevented by incubation with RanGTP (lane 4) but not RanGDP (lane 5). Like these effects on protein/RNA complex formation, the inhibitory action of $\operatorname{Imp} \beta$ on Imp $\alpha$ stimulation of cap methylation (Fig. 5B, columns 2,3 ) was reversed by RanGTP (column 4). RanGDP had no reversing effect (column 5).

\section{Discussion}

MT is essential for the early formation on nuclear premRNAs of $\mathrm{m}^{7} \mathrm{GpppN}$ caps that modulate key events in gene expression (Shuman 1995; Furuichi and Shatkin 2000). Imp $\alpha$ is an adapter protein that cooperates with the receptor $\operatorname{Imp} \beta$ to facilitate nuclear recruitment of NLS-containing proteins (Mattaj and Englmeier 1998; Görlich and Kutay 1999; Nakielny and Dreyfuss 1999). Our results demonstrated cytoplasmic localization of a

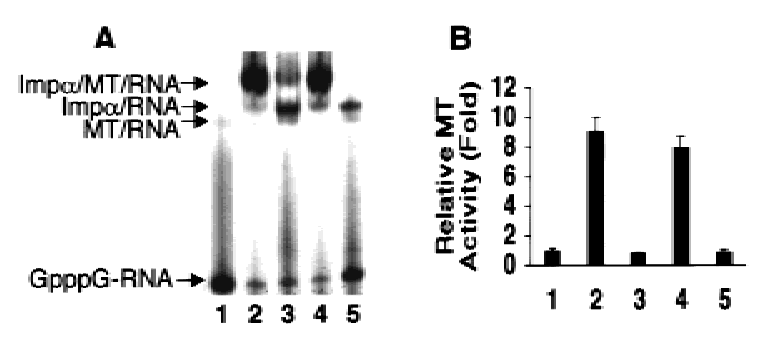

Figure 5. Effect of Ran on protein/RNA complex formation and cap methylation. (A) Samples containing $1 \mu \mathrm{M}$ MT (lane 1) plus $1 \mu \mathrm{M} \operatorname{Imp} \alpha$ (lane 2), plus $3 \mu \mathrm{M} \operatorname{Imp} \beta$ (lane 3 ), plus $5 \mu \mathrm{M}$ RanGTP (lane 4) or RanGDP (lane 5) were incubated with GpppG-RNA and assayed by gel shift as in Fig. 3. (B) Samples containing $3 \mathrm{nM}$ MT (column 1); 3nM MT, $30 \mathrm{nM}$ Imp $\alpha$ (column 2); $3 \mathrm{nM}$ MT, $30 \mathrm{nM} \operatorname{Imp} \alpha, 120 \mathrm{nM} \operatorname{Imp} \beta$ (column 3); 3nM MT, $30 \mathrm{nM} \operatorname{Imp} \alpha, 120 \mathrm{nM} \operatorname{Imp} \beta, 200 \mathrm{nM}$ RanGTP (column 4) or RanGDP (column 5), were assayed for cap methylation as in Fig. 4. truncation mutant of MT that was enzymatically active but missing the $\mathrm{N}$-terminal residues required for $\operatorname{Imp} \alpha$ binding. Surprisingly, the sequences in Imp $\alpha$ necessary for binding MT were in the C-terminal acidic region, not in the NLS-binding domain. In addition, three of the putative NLS sequences in MT (57-RKRK, 80-KKRK, and 194-KKKR) (Tsukamoto et al. 1998) were not required for Imp $\alpha$ binding (Fig. 3A), and simultaneous substitution of alanine at all positions in the fourth (103-KKRKR) had no effect on Imp $\alpha$ binding (data not shown). Although these results suggest that $\mathrm{MT} / \mathrm{Imp} \alpha$ complex formation does not require NLS recognition, additional studies are needed to confirm this point.

$\mathrm{MT} / \mathrm{Imp} \alpha$ complexes were relatively stable as measured by resistance to dissociation by $0.5 \mathrm{M} \mathrm{NaCl}$, implying that the interaction has functional effects in addition to nuclear recruitment of MT. In this regard, we found that MT can directly and selectively recognize transcripts containing 5'-terminal GpppG and that Imp $\alpha$ increased this specific binding and stimulated methylation by 10 -fold (Fig. 4B,C). Our results suggest that $\operatorname{Imp} \beta$ and RanGTP also can modulate MT function. Although Imp $\beta$ bound to GST-MT/Imp $\alpha$ complexes and did not alter MT/Imp $\alpha$ binding (data not shown), its presence prevented both the formation of Imp $\alpha / M T / G p p p G-$ RNA complexes (Fig. 4B) and Imp $\alpha$ stimulation of cap methylation (Fig. 4D). Thus, MT may be transported to the nucleus by $\operatorname{Imp} \alpha / \beta$ heterodimers that separate in response to RanGTP, allowing $\mathrm{MT} / \mathrm{Imp} \alpha$ complexes to bind substrate GpppN-ended pre-mRNAs and resulting in increased cap methylation (Fig. 4C; Herold et al. 1998; Mattaj and Englmeier 1998; Görlich and Kutay 1999; Nakielny and Dreyfuss 1999).

In addition to previous findings that linked CE to transcription elements CTD and Spt5, the present results demonstrating Imp $\alpha$ stimulation of MT indicate that importin protein transporters play a role in mRNA biogenesis. Pol II transcripts that are decapped are rapidly degraded by $5^{\prime}$ exonuclease(s), and capped but unmethylated pre-mRNAs in the nucleus are similarly at risk of degradation as a result of GT reaction reversibility (Furuichi and Shatkin 2000). Methylation of the N7 position on the cap G prevents pyrophosphate-catalyzed GT back reaction and is critical for mRNA stability. Completion of the cap by methylation is important for mRNA downstream events, including splicing, transport to the cytoplasm, and translation. Assuring that caps are methylated may be accomplished at least in part by an early interaction of MT with $\operatorname{Imp\alpha }$, an abundant nuclear transporter that promotes MT selective binding to and methylation of GpppN-ended pre-mRNAs.

\section{Materials and methods}

Yeast two-hybrid screen

MT cDNA was cloned in-frame into the GAL4 DNA-binding domain fusion vector pAS2-1. The Y190 yeast strain containing $H_{S S}{ }^{c}$ and $1 a c Z$ reporter genes was first transformed by pAS2-1-MT, then by the Human Fetal Brain Matchmaker cDNA Library in GAL4 activation domain fusion vector pACT2 (Clontech), using the lithium acetate method. Twelve independent $\mathrm{His}^{+} / \mathrm{lacZ}^{+}$colonies were isolated from $5.1 \times 10^{6}$ transfor- 
mants as described previously (Wen and Shatkin 1999). The plasmids from the positive colonies were retested for interaction using Y190 cotransformed with negative control vectors and then identified by DNA sequencing and GenBank database searches.

In vitro translation

Full-length Imp $\alpha$ cDNA was amplified from the positive clone that contained the entire open reading frame of Imp $\alpha$ by using Advantage-HF polymerase (Clontech) with primers 5'-ATGTCCACCAACGAGAATGC$3^{\prime}$ and $5^{\prime}$-CTAAAAGTTAAAGGTCCCAGG- ${ }^{\prime}$. The polymerase chain reaction $(\mathrm{PCR})$ products were cloned in-frame into $(\mathrm{His})_{6}$-tagged vector pET28a (Novagen) and GST fusion vector pGET-4T-1 (Pharmacia). Truncation mutants of Imp $\alpha$ were generated from full-length Imp $\alpha$ by PCR and cloned into vector pET28a. pET28a-Imp $\alpha$ and its truncation mutants were transcribed and translated in vitro by TNT Quick Coupled Transcription/Translation System (Promega) as described previously (Wen and Shatkin 1999).

Expression and purification of Imp $\alpha$ and $M T$ recombinant proteins pGEX-4T-1-Imp $\alpha$ was introduced into BL21(DE3) cells. GST-Imp $\alpha$ was expressed in the presence of $0.8 \mathrm{mM}$ IPTG for $4 \mathrm{~h}$ at $37^{\circ} \mathrm{C}$ and purified on glutathione-agarose (Sigma) as described (Wen et al. 1998).

The expression of recombinant MT was induced by $0.8 \mathrm{mM}$ IPTG for $17 \mathrm{~h}$ at $17^{\circ} \mathrm{C}$, and purification was performed as described previously (Pillutla et al. 1998).

MT truncation mutants were generated from full-length MT by PCR and cloned into pGEX-4T-1. The expression and purification were performed as described for full-length MT

Expression and purification of $\operatorname{Imp} \beta$

Imp $\beta$ cDNA was isolated from human HeLa Marathon-Ready cDNA (Clontech) with primers 5'-ATGGAGCTGATCACCATTCTC-3' and 5'. TCAAGCTTCGTTCTTCAGTTTCC-3'. The PCR products were cloned into $\mathrm{pET} 28 \mathrm{a}$. His-tagged Imp $\beta$ was expressed in the presence of $0.8 \mathrm{mM}$ IPTG for $4 \mathrm{~h}$ at $37^{\circ} \mathrm{C}$ and purified on Ni-NTA agarose (Qiagen) as described (Wen et al. 1998).

Cloning, expression, purification, and nucleotide loading of Ran Ran cDNA was isolated from human HeLa Marathon-Ready cDNA, us-

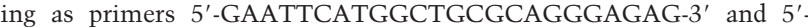
CTCGAGTCACAGGTCATCATCCTC-3'. The PCR products were cloned into pGEX-4T-1, and expression and purification were performed as described (Wen et al. 1998). Ran (10 $\mu \mathrm{M})$ was incubated for $30 \mathrm{~min}$ on ice with $1.0 \mathrm{mM}$ GTP or GDP in $5 \mathrm{mM}$ EDTA, $20 \mathrm{mM}$ Tris (pH 7.5), 100 $\mathrm{mM} \mathrm{KCl}, 20 \mathrm{mM} \mathrm{MgCl}$, as described by Floer and Blobel (1996). Unbound nucleotide was removed by Chroma Spin+TE-10 (Clontech).

GST pulldown

These assays were performed as described previously (Wen and Shatkin 1999 ) in the presence of $0.1,0.2$, or $0.5 \mathrm{M} \mathrm{NaCl}$.

\section{Coimmunoprecipitation}

pEGFP-C1-Imp $\alpha$ and pcDNA3.1|+|-MT-myc were cotransfected into HeLa S3 cells with Superfect Transfection Reagent (Qiagen). After $48 \mathrm{~h}$, cells were lysed in RIPA buffer $(0.1 \%$ SDS, $1 \%$ Triton X-100, $1 \%$ sodium deoxycholate, $150 \mathrm{mM} \mathrm{NaCl}, 10 \mathrm{mM}$ Tris- $\mathrm{HCl}$ at $\mathrm{pH} 7.4,1 \mathrm{mM}$ EDTA, $0.5 \mathrm{mM}$ phenylmethylsulfonyl fluoride), immunoprecipitated with antimyc or anti-GFP antibodies (Santa Cruz Biotechnology), and immunoblotted with anti-GFP or anti-myc antibodies.

\section{Subcellular localization}

MT and MT (144-476) were ligated into GFP fusion vector pEGFP-C1, and Imp $\alpha$ was cloned into RFP fusion vector pDsRed1-N1 (Clontech). The plasmids were transfected into HeLa cells by SuperFect. After $36 \mathrm{~h}$, cells were fixed by $4 \%$ paraformaldehyde in PBS and visualized by fluorescence microscopy.

\section{MT activity}

Enzyme activity was measured as described previously (Pillutla et al 1998).
Gel mobility shift assay

T7 Polymerase 32-nt runoff transcripts were synthesized (RiboProbe In Vitro Transcription System, Promega) from BamHI-linealized pGEM-1 (Promega) in the presence of $\left[\alpha{ }^{32} \mathrm{P}\right] \mathrm{GTP}(3000 \mathrm{Ci} / \mathrm{mmole}$; Amersham) and cap analogs. Purified transcripts containing 5 '-terminal pppG, GpppG, or $\mathrm{m}^{7} \mathrm{GpppG}$ were incubated for $30 \mathrm{~min}$ at $4^{\circ} \mathrm{C}$ with $\mathrm{MT}$ in 20 $\mathrm{mM}$ Tris (pH 7.9), $50 \mathrm{mM} \mathrm{KCl}, 10 \mathrm{mM} \mathrm{MgCl} 2,5 \mathrm{mM}$ DTT, $1 \mathrm{mg} / \mathrm{mL}$ BSA, 7.5\% glycerol, $20 \mathrm{U}$ of RNase inhibitor, $50 \mu \mathrm{M} S$-adenosyl homocysteine. Free and bound species were resolved at $4^{\circ} \mathrm{C}$ by $4.5 \%$ native PAGE (Buratowski and Chodosh 1996) and quantitated by PhosphorImager (Molecular Dynamics).

\section{Acknowledgments}

We thank J. Bauman and C. Dharia for assistance and Drs. C. Gélinas, A.B. Rabson, and D. Reinberg for critical comments.

The publication costs of this article were defrayed in part by payment of page charges. This article must therefore be hereby marked "advertisement" in accordance with 18 USC section 1734 solely to indicate this fact.

\section{References}

Buratowski, S. and Chodosh, L.A. 1996. Mobility shift DNA-binding assay using gel electrophoresis. In Current protocols in molecular biology (ed. F.M. Ausubel, et al.), pp. 12.2.1-12.2.11. John Wiley, New York.

Cho, E., Takagi, T., Moore, C.R., and Buratowski, S. 1997. mRNA capping enzyme is recruited to the transcription complex by phosphorylation of the RNA polymerase II carboxy-terminal domain. Genes \& Dev. 11: 3319-3326.

Floer, M. and Blobel, G. 1996. The nuclear transport factor karyopherin $\beta$ binds stoichiometrically to Ran-GTP and inhibits the Ran GTPase activating protein. J. Biol. Chem. 271: 5313-5316.

Furuichi, Y. and Shatkin, A.J. 1994. In RNA processing II, (ed. S.J. Higgins and B.D. Hames), pp. 35-67. Oxford University Press, Oxford. . 2000. Viral and cellular mRNA capping: Past and prospects. $A d v$. Virol. Res. 55: 135-184.

Görlich, D. and Kutay, U. 1999. Transport between the cell nucleus and the cytoplasm. Annu. Rev. Cell Dev. Biol. 15: 607-660.

Görlich, D., Kraft, R., Kostka, S., Vogel, F., Hartmann, E., Laskey, R.A., Mattaj, I.W., and Izaurralde, E. 1996. Importin provides a link between nuclear protein import and U snRNA export. Cell 87: 21-32.

Herold, A., Truant, R., Wiegand, H., and Cullen, B.R. 1998. Determination of the functional domain organization of the importin alpha nuclear import factor. J. Cell Biol. 143: 309-318.

Ho, C.K. and Shuman, S. 1999. Distinct roles for CTD Ser-2 and Ser-5 phosphorylation in the recruitment and allosteric activation of mammalian mRNA capping enzyme. Mol. Cell 3: 405-411.

Kohler, M., Speck, C., Christiansen, M., Bischoff, F.R., Prehn, S., Haller H., Görlich, D., and Hartmann, E. 1999. Evidence for distinct substrate specificities of importin $\alpha$ family members in nuclear protein import. Mol. Cell. Biol. 19: 7782-7791.

Mao, X., Schwer, B., and Shuman, S. 1995. Yeast mRNA cap methyltransferase is a 50-kilodalton protein encoded by an essential gene. Mol. Cell. Biol. 15: 4167-4174.

Mattaj, I.W. and Englmeier, L. 1998. Nucleocytoplasmic transport: The soluble phase. Annu. Rev. Biochem. 67: 265-303.

McCracken, S., Fong, N., Rosonina, E., Yankulov, K., Brothers, G., Siderovski, D., Hessel, A., Foster, S., Shuman, S., and Bentley, D.L. 1997. 5 '-Capping enzymes are targeted to pre-mRNA by binding to the phosphorylated carboxy-terminal domain of RNA polymerase II. Genes \& Dev. 11: 3306-3318

Nakielny, S. and Dreyfuss, G. 1999. Transport of proteins and RNAs in and out of the nucleus. Cell 99: 677-690.

Pillutla, R., Yue, Z., Maldonado, E., and Shatkin, A.J. 1998. Recombinant human mRNA cap methyltransferase binds capping enzyme/RNA polymerase IIo complexes. J. Biol. Chem. 273: 21443-21446.

Saha, N., Schwer, B., and Shuman, S. 1999. Characterization of human, Schizosaccharomyces pombe, and Candida albicans mRNA cap methyltransferases and complete replacement of the yeast capping apparatus by mammalian enzymes. J. Biol. Chem. 274: 16553-16562. 
Shuman, S. 1995. Capping enzyme in eukaryotic mRNA synthesis. Prog. Nucleic Acids Res. Mol. Biol. 50: 101-129.

Tsukamoto, T., Shibagaki, Y., Niikura, Y., and Mizumoto, K. 1998. Cloning and characterization of three human cDNAs encoding mRNA (guanine-7-)-methyltransferase, an mRNA cap methyltransferase. Biochem. Biophys. Res. Commun. 251: 27-34.

Weis, K., Mattaj, I.W., and Lamond, A.I. 1995. Identification of hSRP1 $\alpha$ as a functional receptor for nuclear localization sequences. Science 268: 1049-1053.

Wen, Y. and Shatkin, A.J. 1999. Transcription elongation factor hSPT5 stimulates mRNA capping. Genes \& Dev. 13: 1774-1779.

Wen, Y., Yue, Z., and Shatkin, A.J. 1998. Mammalian capping enzyme binds RNA and uses protein tyrosine phosphatase mechanism. Proc. Natl. Acad. Sci. 95: 12226-12231.

Yokoska, J., Tsukamoto, T., Miura, K., Shiokawa, K., and Mizumoto, K. 2000. Cloning and characterization of mRNA capping enzyme and mRNA (guanine-7-)-methyltransferase cDNAs from Xenopus laevis. Biochem. Biophys. Res. Commun. 268: 617-624.

Yue, Z., Maldonado, E., Pillutla, R., Cho, H., Reinberg, D., and Shatkin, A.J. 1997. Mammalian capping enzyme complements mutant Saccharomyces cerevisiae lacking mRNA guanylyltransferase and selectively binds the elongating form of RNA polymerase II. Proc. Natl Acad. Sci. 94: 12898-12903. 


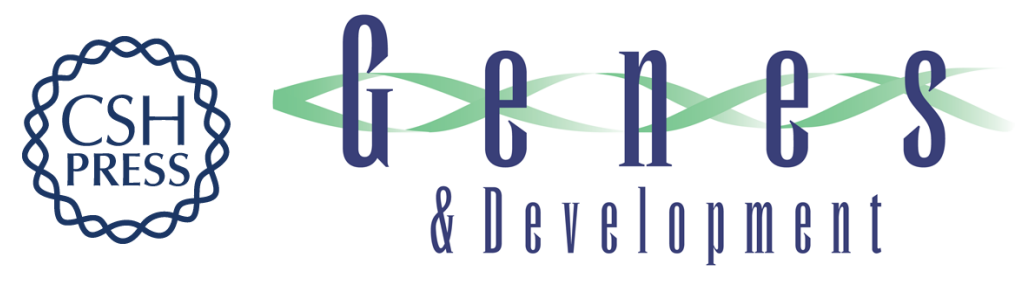

\section{Cap methyltransferase selective binding and methylation of GpppG-RNA are stimulated by importin- $\alpha$}

Yingxia Wen and Aaron J. Shatkin

Genes Dev. 2000, 14:

Access the most recent version at doi:10.1101/gad.848200

References This article cites 21 articles, 12 of which can be accessed free at: http://genesdev.cshlp.org/content/14/23/2944.full.html\#ref-list-1

License

Email Alerting

Receive free email alerts when new articles cite this article - sign up in the box at the top Service right corner of the article or click here.

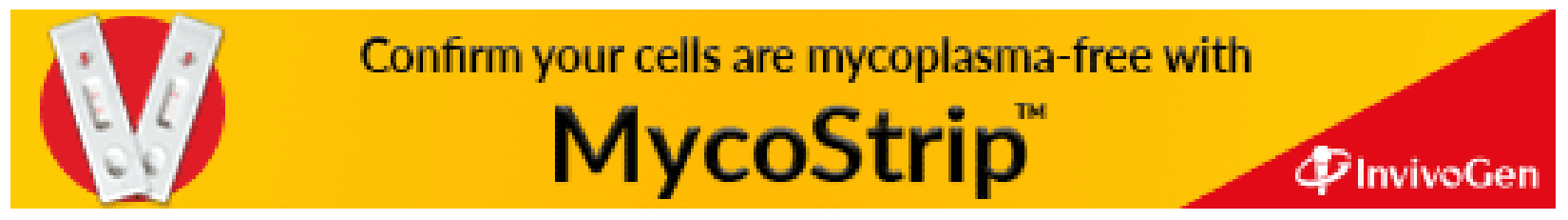

